\title{
Comparison of Greenhouse Fuel Consumption Calculated Using Different Methods with Actual Fuel Consumption
}

\author{
Abdullah Nafi Baytorun ${ }^{1 *}$, Zeynep Zaimoğlu ${ }^{2}$, Adil Akyüz ${ }^{3}$, Sait Üstün ${ }^{3}$, Ali Çaylı ${ }^{3}$ \\ ${ }^{1}$ Department of Agricultural Structures and Irrigation, Faculty of Agriculture, Çukurova University, 01250 Adana, Turkey \\ ${ }^{2}$ Department of Environmental Engineering, Faculty of Engineering, Cukurova University, 01250 Adana, Turkey \\ ${ }^{3}$ Department of Biosystem Engineering, Faculty of Agriculture, Kahramanmaras Sutcu Imam University, 46040 Kahramanmaras, Turkey
}

\section{A R T I C L E IN F O}

\section{Research Articles}

Received 22 January 2018

Accepted 15 May 2018

\section{Keywords:}

Greenhouse

Greenhouse heating

Heat requirement

ISIGER-SERA

Fuel consumption

$\overline{{ }^{*} \text { Corresponding Author: }}$

\section{A B S T R A C T}

Heat requirements in greenhouses are calculated considering greenhouse type, the climate of the region and temperatures desirable for plant growth. Calculations made according to daily average temperature values lead to misleading results during periods when temperatures are high and under conditions when greenhouse temperature is kept low. For this reason, determining heat requirements according to hourly values provides more accurate results. Calculations of heat requirements in greenhouses are based on the difference between the desired temperature in the greenhouse and the outside temperature. However, in unheated greenhouses and those that are not ventilated until a specific temperature, actual temperature values are higher than outside temperatures. For this reason, heat requirement calculations should be made according to hourly climate values taking into account actual temperature in the greenhouse and temperature rise resulting from greenhouse specifications. This study aims to compare the amounts of fuel consumed under real conditions with fuel consumption calculated with conventional methods using inside and outside temperature difference and considering the above mentioned inconveniences. Daily fuel consumption calculated theoretically differs from actual consumption values. However, in comparisons based on fuel amounts consumed on an annual basis, best results were obtained when temperature rise in the greenhouse was taken into consideration. In the event that temperature rise is taken into consideration, a $3 \%$ difference is observed between calculated fuel consumption and actual fuel consumption.

\section{Seralarda farklı Yöntemlere göre hesaplanan yakıt tüketiminin gerçek yakıt tüketimi ile karşılaştırılması}

M A K A L E B İ L G İ S İ

\section{Araștırma Makalesi}

Geliş 22 Ocak 2018

Kabul 15 Mayıs 2018

\section{Anahtar Kelimeler:}

Sera

Seralarda isitma

Is1 gereksinimi

ISIGER-SERA

Yakıt tüketimi

"Sorumlu Yazar:

E-mail: baytorun@cu.edu.tr
Ö Z

Seralarda 1S1 gereksinimi, seranın tipine, donanımına, sera kurulacak yerin iklim özelliklerine ve bitkilerin arzu ettiği sıcaklığa bağlı olarak hesaplanmaktadır. Günlük ortalama sıcaklık değerlerine göre yapılan hesaplamalar, sicaklığın yüksek olduğu dönemlerde ve serada sıcaklığın düşük tutulduğu koşullarda hatalı sonuçlar vermektedir. Belirtilen nedenle 1s1 gereksiniminin saatlik değerlere göre belirlenmesi daha sağlıklı sonuçlar vermektedir. Serada isı gereksinimi hesaplamalarında serada arzulanan sıcaklık ile dış sıcaklık arasındaki fark esas alınmaktadır. Oysa 1sıtılmayan ve belirli bir sıcaklığa kadar havalandırılmayan seralarda ortaya çıkan gerçek sıcaklık değerleri, dış sıcaklık değerlerinden yüksektir. Belirtilen nedenle 1sı gereksinimi hesaplanmaları, serada ortaya çıkan gerçek sıcaklık ve seranın özelliğine bağlı sıcaklık yükselmesi dikkate alınarak saatlik iklim değerlerine göre yapılmalıdır. Yapılan bu çalışmada; alışılagelmiş yöntemle iç-dış sıcaklık farkına göre ve yukarıda belirtilen sakıncalar dikkate alınarak yapılan hesaplamalar gerçek koşullarda tüketilen yakıt miktarları ile karşıllaştırılmıştır. Teorik olarak hesaplanan günlük yakıt tüketimleri gerçek tüketim değerlerinden farklılıklar göstermiştir. Ancak yıllık bazda tüketilen yakıt miktarları esas alınarak yapılan karşılaştırmalarda, en uygun sonuçlar serada sıcaklık yükselmesinin dikkate alınması durumunda elde edilmiştir. Sicaklık yükselmesinin dikkate alınması durumunda elde edilen yakıt gerçek tüketimle \%3 farklılık göstermiştir. 


\section{Introduction}

Depending on the climate of the region where they are installed, greenhouses have heating requirements during cold periods and ventilation, shading and/or cooling requirements during hot periods. While heating improves efficiency and quality, it leads to a considerable increase in production costs. von Zabeltitz (2011) calculated the amount of fuel (fuel oil) required in greenhouses in Antalya during the period of December-February as 7 L. $\mathrm{m}^{-2} \cdot \mathrm{a}^{-1}$ in the event that the greenhouses are heated only at night and temperature is kept at $16^{\circ} \mathrm{C}$.This value is considerably lower than the fuel consumption in Northern European countries. In the Netherlands, where modern greenhousing is a common practice, 13 times more energy is consumed to produce one kilogram of tomatoes than in Spain (von Zabeltitz. 2011). When greenhouses with thermal curtains on the Mediterranean coastline are heated regularly, heating expenses make up $20 \%$ of the total production cost (Baytorun, 2016).

Heat requirements in greenhouses are calculated according to the principles specified in DIN 4701 standards by taking into consideration greenhouse type, greenhouse equipment, the climate of the region and temperatures desirable for plant growth. Heat requirements in greenhouses are mainly calculated according to average temperature values. However, during transition periods when temperatures are high and under conditions when greenhouse temperature is kept low, calculations made using average temperature values lead to inaccurate results (Tantau, 1983). It has been observed that there is no need for greenhouse heating when average outside temperature is $16^{\circ} \mathrm{C}$ and the desired temperature in the greenhouse is $16^{\circ} \mathrm{C}$. However, the average temperature $16^{\circ} \mathrm{C}$ includes temperature values below and above this value. Thus, no heat requirement calculations are made when average temperature is high even though heating is necessary during certain hours of the day.

Based on the principles specified in DIN 4701 standards, heat requirement calculations are made in different ways. Öztürk (2011) determined heat requirement in greenhouses installed in Antalya assuming average heat power values he determined for the lowest temperature values of each month and the heating time in the greenhouse. Çanakçı et al. (2013) calculated greenhouse heat requirement for Antalya taking into consideration average temperatures during night hours and the length of night.

Damrath and Klein (1983) Trier (Germany) calculated heat energy requirement based on the principles specified in DIN 4701 standards by taking into account hourly values. In his study, Damrath (1980) determined heat requirement as an average of the hourly values he calculated for many years.

von Zabeltitz (2011) calculated heat energy requirement for plastic greenhouses in Mediterranean countries using Hallaire's method and considering the lowest temperature values and day length values due to latitude. In the same work, von stated that the most accurate calculation for heat energy requirement could be made using hourly climatic values.
Heat energy requirement of greenhouses is equal to the sum of the heat power values calculated according to hourly values (Meyer, 2008). According to the principles stated in DIN 4701 standards, calculations using hourly climatic values are based on the difference between the desired temperature in the greenhouse and outside temperatures. However, in unheated greenhouses and those that are not ventilated until a specific temperature, temperature values are different from outside temperatures.

Furthermore, depending on the greenhouse specifications, some of the solar energy is stored within the greenhouse. Heat energy stored throughout the day leads to a temperature rise in the greenhouse. For this reason, considering temperature rises due to the heat storage specifications of greenhouses will lead to more accurate results (Rath, 1992; Tantau, 2008; Baytorun et al., 2016). Temperature rise in the greenhouse varies according to the difference between average temperatures during day hours and average temperatures of succeeding night hours (Rath, 1992; 1994). In his study, Rath (1992) states that maximum temperature rise in insulated glass greenhouses in the climatic conditions of Germany could be taken as $7^{\circ} \mathrm{C}$. Rath has based his claim on the experiences of specialists.

In his modal study, Rath (1994) used an empirical equation to express the rise in greenhouse temperature due to the difference between average temperature during day hours and average temperature of succeeding night hours.

$$
\Delta \theta=\frac{1}{20} \times s \times Z
$$

In the equation, $\mathrm{s}$ is a coefficient varying between 2 and $10 \mathrm{~K}$ depending on the greenhouse specifications while $\mathrm{Z}$ is the difference between average temperature during day hours and average temperature of succeeding night hours.

Baytorun et al. (1995) determined night temperature rises in unheated plastic greenhouses in the Mediterranean climatic conditions (Adana) as $-0.5^{\circ} \mathrm{C}$ to $1.6^{\circ} \mathrm{C}$. von Zabeltitz (2011) says that when calculating heat requirement for greenhouses in the Mediterranean countries, heat rise could be taken as $1-2^{\circ} \mathrm{C}$.

Heat requirements in greenhouses change according to the technical equipment of the greenhouse. Impermeability of thermal curtains used in greenhouses affects heat requirements. In his study carried out in areas of implementation, Müller (1987) concluded that savings changed significantly with the insulation of thermal curtains. Based on the results of Müller's studies, Rath (1992) developed correction coefficients depending on the insulation of thermal curtains.

Heat consumption is also affected by the type and layout of heating systems. While installation of heating pipes on the greenhouse floor space leads to decreases in heat loss, installation of heating pipes above or operation of blow air heating systems at low levels will increase heat consumption (Tantau, 1983). 
For the above mentioned reasons, heat requirements in greenhouses should be determined based on hourly climatic values (temperature, radiation, wind speed) by taking into consideration the greenhouse equipment, actual temperature values in the greenhouse and heat rise resulting from greenhouse specifications (Rath, 1992; Tantau, 2008; Baytorun et al., 2016).

Baytorun et al. (2016) developed the ISIGER-SERA specialized system to determine heat requirements in greenhouses and calculate the parameters necessary for planning heating systems. The ISIGER-SERA specialized system calculates heat requirements in greenhouses by taking into account the temperature rises resulting from the actual temperature in the greenhouse and type of the greenhouse (glass, plastic).

This study aims to calculate the heat requirement and fuel consumption of a modern greenhouse in Adana with the ISIGER-SERA specialized system, according to DIN 4701 standards and based on hourly climatic values by taking into consideration total heat requirement coefficient which varies with the hourly wind speed of the region and to compare these values with the actual consumption values of a modern plastic greenhouse in implementation.

\section{Material and Method}

The study was carried out on a high technology $20,160 \mathrm{~m}^{2} \mathrm{PE}$ plastic greenhouse installed in Adana. The roof of the greenhouse is covered with single layer PE plastic $(180 \mu)$ and its side walls are covered with double layer polycarbonate (PC $8 \mathrm{~mm})$. The dimensions of the greenhouse are given in Table 1 . Total heat transmission coefficient needed for heat requirement calculations $\left(U_{c S}\right)$ has been taken as $7.0 \mathrm{Wm}^{-2} \mathrm{~K}^{-1}$ for single layer PE plastic and $4.7 \mathrm{~W} \mathrm{~m}^{-2} \mathrm{~K}^{-1}$ for double layer polycarbonate (PC-8 mm) (Tantau 1983. von Zabeltitz 1986).

The plastic greenhouse used in carrying out this study was heated regularly and imported coal was utilized. In the greenhouse, heating pipes of $51 \mathrm{~mm}$ in diameter were installed near the greenhouse floor between plant rows. The lower calorific value $\left(H_{u}\right)$ of the imported coal used for heating is $8.14 \mathrm{kWh} \cdot \mathrm{kg}^{-1}$. Heat in the grenhouse was controlled by regulating water temperature with three-way distribution valves. Imported coal consumed throughout the production period was recorded on a daily basis. Heat energy sent to the greenhouse based on daily consumption of coal was calculated with equation 1 (Tantau 1983).

$$
Q=B_{y} \times H_{u} \times \eta
$$

In the equation:

$Q \quad$ : Heat energy [kWh]

$B_{y}$ : Coal consumption $[\mathrm{Kg}]$

$H_{u}$ : Lower calorific value of coal $\left[\mathrm{kWh} . \mathrm{Kg}^{-1}\right]$

$\eta \quad$ : Efficiency of the heating system [-] [taken as 0.60]

In the greenhouse used in carrying out this study, tomatoes were grown in culture without soil. In every $\mathrm{m}^{2}$ of the greenhouse 2.5 tomato seedlings were planted. Irrigation was carried out automatically with spaghetti drippers in such a way that each seedling was irrigated by one dripper.

In order to conserve heat energy within the greenhouse, XLS 15 thermal curtainswere used. The thermal curtains were closed when solar radiation was 0 $\mathrm{W} . \mathrm{m}^{-2}$ and retracted gradually within approximately 30 minutes.

Outside climatic values and temperature, humidity, solar radiation and water flow temperatures in the greenhouse were recorded every minute and recorded as hourly averages by a climate computer. Based on the measured climatic values, the temperature in the greenhouse was kept at $16^{\circ} \mathrm{C}$ using control elements.

Temperature, wind and solar radiation values for Adana (35 E 18; $37 \mathrm{~N} \mathrm{01)}$ needed to calculate heat requirement in the greenhouse were obtained from the 25 year hourly values provided by the State Meteorological Service.

Calculating Total Heat Transmission Coefficient Based on Wind Speed

Depending on wind speed, total heat transmission coefficient $\left(U_{c S}\right)$ shows an increasing linear change (von Zabeltitz, 1986). As insulation of the greenhouse is increased, change depending on wind speed decreases (Tantau, 2012). The change $U_{c S}$ coefficient depending on wind speed was calculted with equation 2 (Rath, 1992).

$$
U_{c s}=U+\frac{U}{x_{1}} \times\left(x_{2} \times v_{w}+x_{3}\right)
$$

$U \quad$ :Heat transmission coefficient of covering material at $4 \mathrm{~m} \cdot \mathrm{s}^{-1}$ wind speed $\left[\mathrm{W} \cdot \mathrm{m}^{-2} \mathrm{~K}^{-1}\right]$

$U_{c s}$ :Total heat transmission coefficient of covering material corrected according to wind speed [W. $\mathrm{m}^{-2} \mathrm{~K}^{-1}$ ]

$v_{w} \quad:$ Wind speed $\left[\mathrm{m} \cdot \mathrm{s}^{-1}\right]$

$$
x_{1}=7.56[-], \quad x_{2}=0.35\left[\mathrm{~s} \mathrm{~m}^{-1}\right], x_{3}=-1.4[-]
$$

Calculating Greenhouse Heat Consumption Based On Temperature Rise (Method 1)

Unlike conventional heat requirement calculations made using outside temperature, calculations made with this method take into account actual temperature in unheated greenhouses or those that are not ventilated until a specific temperature as well as temperature rise due to greenhouse specifications. By taking into consideration heat rises in the greenhouse, heat requirement calculations were made with equation 3 (Rath.1992).

$$
\begin{aligned}
& \Phi_{c S}=\sum_{n=1}^{8760}\left(\left(\left(\theta_{i_{n}}-\theta_{i . o H_{n}}-\Delta \theta_{S p_{n}}\right) \times U_{c S} \times A_{H} \times\right.\right. \\
& \left.\left.\left(1-E E_{E S}\right)\right) \times t\right) \\
& \theta_{i . o H} \quad \begin{array}{l}
\text { :Actual temperature in the unheated } \\
\text { greenhouse }\left[{ }^{\circ} \mathrm{C}\right]
\end{array} \\
& \Delta \theta_{S p} \quad \begin{array}{l}
\text { :Temperature rise due to greenhouse } \\
\text { specifications }\left[{ }^{\circ} \mathrm{C}\right] .
\end{array}
\end{aligned}
$$


Table1 Dimensions of the greenhouse used in calculations.

\begin{tabular}{l|ccccc}
\hline \multicolumn{1}{c|}{ Number of divisions } & (Number) & 21 & Side wall area & $\left(\mathrm{m}^{2}\right)$ & $1,000.00$ \\
\hline Division width & $(\mathrm{m})$ & 9.60 & Front area & $\left(\mathrm{m}^{2}\right)$ & $2,722.56$ \\
Greenhouse length & $(\mathrm{m})$ & 100.00 & Roof area & $\left(\mathrm{m}^{2}\right)$ & $23,617.76$ \\
Side wall height & $(\mathrm{m})$ & 5.00 & Cover surface area & $\left(\mathrm{m}^{2}\right)$ & $27,340.32$ \\
Roof height & $(\mathrm{m})$ & 2.50 & Floor area & $\left(\mathrm{m}^{2}\right)$ & $20,160.00$ \\
Ridge height & $(\mathrm{m})$ & 7.50 & $\mathrm{~A}_{\mathrm{H}} / \mathrm{A}_{\mathrm{G}}$ & $(-)$ & 1.36 \\
\hline
\end{tabular}

Table 2 Correction coefficients based on impermeability of thermal curtains*

\begin{tabular}{l|c}
\hline \multicolumn{1}{c|}{ Impermeability of thermal curtain } & $\mathrm{KF}_{\mathrm{ES}}$ \\
\hline Good & 6.8 \\
Average & 11.05 \\
Poor & 29.43 \\
No thermal curtain & 0 \\
\hline
\end{tabular}

*(Rath,1992)

\section{Calculating the Effect of Thermal Curtains}

Savings provided by thermal curtains used in greenhouses vary according to curtain material, texture and impermeability. Energy saving values depending on good, average and poor insulation of thermal curtains were calculated with equation 4 according to results obtained and taking into account the correction factor $\left(K F_{E S}\right)$ (Table 2) determined by (Rath.1992). $U_{C S} \leq 10$ ve $E E_{E S} \leq 0.6$ under these conditions, $E E_{E S}$ was calculated with equation 4 .

$$
E E_{E S}=\frac{E E_{E S . S t}}{K F_{E S}} \times U_{c S}
$$

$E E_{E S . S t}$ :Heat energy savings of thermal curtain [-]

$K F_{E S}$ :Correction coefficient for thermal curtain (W. $\left.\mathrm{m}^{-2} \mathrm{~K}^{-1}\right)$

Calculating Actual Temperature $\left(\theta_{\text {i.oH }}\right)$ Values in Unheated in Unheated Greenhouses and Those That Are Not Ventilated Until A Specific Temperature

In order to determine the actual temperature value in unheated in unheated greenhouses and those that are not ventilated until a specific temperature, it is first necessary to calculate the theoretical temperature in the greenhouse with equation 5 . In the calculations, factor for conversion to perceptible heat of solar energy reaching the greenhouse $(\eta)$ was taken as 0.70 (Tantau 1983, von Zabeltitz 1986).

$$
\theta_{i . t h}=\frac{q_{G S} \times \tau \times}{U_{c S} \times\left(1-E E_{E S}\right) \times A_{H}}+\theta_{a}
$$

In the equation:

$\theta_{\text {i.th }}$ :Theoretical temperature in unheated unventilated greenhouse $\left({ }^{\circ} \mathrm{C}\right)$

Temperature in the unheated greenhouse $\left(\theta_{\text {i.oH }}\right)$ was determined with the logical relations given in equation 6 by taking into consideration the calculated theoretical temperature $\left(\theta_{i . t h}\right)$, ventilation temperature and outside temperature (Rath, 1992).

$$
\left.\begin{array}{c}
\theta_{i . t h} \geq \theta_{L} \text { ve } \theta_{L} \geq \theta_{a} \\
\theta_{i . t h}<\theta_{L} \text { ve } \theta_{i . t h}>\theta_{a} \\
\text { If not }
\end{array}\right\} \theta_{i . o H}=\left\{\begin{array}{c}
\theta_{L} \\
\theta_{i . t h} \\
\theta_{a}
\end{array}\right.
$$

$\theta_{L} \quad:$ Ventilation temperature $\left({ }^{\circ} \mathrm{C}\right)$

$\theta_{i . S}$ : Desired temperature in the greenhouse $\left({ }^{\circ} \mathrm{C}\right)$

Based on the temperature set in the greenhouse $\left(\theta_{i . S}\right)$, inside temperature value used for heat requirement calculations in equation $3\left(\theta_{i}\right)$ was determined with the logical relations 7 .

$$
\left.\begin{array}{c}
\theta_{i . o H} \leq \theta_{i . s} \\
\text { If not }
\end{array}\right\} \theta_{i}=\left\{\begin{array}{c}
\theta_{i . S} \\
\theta_{i . o H}
\end{array}\right.
$$

Determining Temperature Rise $\left(\Delta \theta_{S p}\right)$ Due to Greenhouse Specifications

Temperature rise in the greenhouse varies firstly with the day and night temperature difference, secondly with the energy storage property of the greenhouse and thirdly with the total heat transmission coefficient $\left(U_{C S}\right)$ under conditions when high heat energy is required $\left(\Delta \theta_{(\mathrm{i}-\mathrm{a})} \geq 20\right)$ (Rath, 1992).

In the calculations, maximum temperature rise in the greenhouse $\left(\Delta \theta_{\text {Sp.max }}\right)$ was taken as $1^{\circ} \mathrm{C}$ by taking into consideration the measurements made in unheated PE plastic greenhouses in the Mediterranean region (Baytorun et al. 1995). This value was accepted as the adaptation value for the model used in calculations. Based on the temperature values in the unheated greenhouse $\left(\theta_{i . o H}\right)$, temperature rise depending on the current heat storage potential $\left(\Delta \theta_{S p . p o t}\right)$ was calculated with equations 8 and 9.

$$
\begin{aligned}
& \Delta \theta_{\text {Sp.pot }}=\frac{Z_{d}}{\max \left(Z_{2 \ldots . .365}\right)} * \Delta \theta_{\text {Sp.max }} \\
& Z_{d}=\overline{\theta_{i . o H . D a y_{d-1}}}-\overline{\theta_{\text {i.oH.Night }}}
\end{aligned}
$$

In the equations:

$\Delta \theta_{\text {Sp.pot }}:$ Temperature rise in the greenhouse due to current heat storage potential $\left({ }^{\circ} \mathrm{C}\right)$.

$\Delta \theta_{\text {Sp.max }}$ :Maximum temperature rise in the unheated greenhouse $\left(1^{\circ} \mathrm{C}\right)$.

$Z_{d} \quad$ :Difference between average temperatures at night $\left(q_{G S}=0\right)$ and day $\left(q_{G S}>0\right)$ hours in the unheated greenhouse $\left({ }^{\circ} \mathrm{C}\right)$. 
Temperature rise in the greenhouse due to heat storage potential $\left(\Delta \theta_{S p}\right)$ was determined with the logical relations given in equation 10 (Rath, 1992).

$$
\begin{aligned}
& \Delta \theta_{\text {Sp.pot }} \geq 20 \\
& \left.\begin{array}{c}
\theta_{i}-\theta_{\text {i.OH }} \leq \Delta \theta_{\text {Sp.pot }}<20 \\
0<\Delta \theta_{\text {Sp.pot }}<\theta_{i}-\theta_{i . O H}<20 \\
\text { If not }
\end{array}\right\} \Delta \theta_{S p}= \\
& \left\{\begin{array}{c}
\Delta \theta_{\text {Sp.pot }} \text { If not } \\
\Delta \theta_{\text {Sp.pot }} \\
\frac{\Delta \theta_{\text {Sp.pot }} \cdot\left(\theta_{i}-\theta_{\text {i.OH }}-20\right)}{\Delta \theta_{\text {Sp.pot }}-20} \\
0
\end{array}\right.
\end{aligned}
$$

Calculating Greenhouse Heat Requirement Based on Temperature Difference (Method 2)

Heat consumption based on temperature difference considering hourly climatic values was calculated with equation 11 .

$$
\begin{aligned}
\Phi_{c S} & =\sum_{n=1}^{8760}\left(U_{c S} \times A_{H} \times\left(\theta_{i}-\theta_{a}\right)-\left(A_{G} \times q_{G S} \times\right.\right. \\
\tau \times \eta)) & *\left(1-E E_{E S}\right) \times t
\end{aligned}
$$

In the equation:

$\Phi_{c s}$ :Heat consumption throughout production $\operatorname{period}\left(\mathrm{Wh} \cdot \mathrm{a}^{-1}\right)$

$U_{c s}$ :Total heat transmission coefficient of the covering material $\left(\mathrm{W} \cdot \mathrm{m}^{-2} \mathrm{~K}^{-1}\right)$

$A_{H} \quad$ :Covering surface area $\left(\mathrm{m}^{2}\right)$

$\theta_{i} \quad$ :Desired temperature in the greenhouse $\left({ }^{\circ} \mathrm{C}\right)$

$\theta_{a}$ :Outside temperature $\left({ }^{\circ} \mathrm{C}\right)$

$A_{G}$ :Greenhouse floor area $\left(\mathrm{m}^{2}\right)$

$q_{G S}:$ Solar radiation value $\left(\mathrm{W} . \mathrm{m}^{-2}\right)$

$\tau \quad$ :Permeability of covering material(-)

$\eta \quad$ :Factor for conversion to perceptible heat(-)

$E E_{E S}:$ Heat saving due to thermal curtain(-)

$t \quad$ :Time frame in the simulation $(\mathrm{h}=1)(\mathrm{h})$

\section{Result and Discussion}

During the study, the temperature in the greenhouse was set to $16^{\circ} \mathrm{C}$. Changes in nightly averages of greenhouse and outside temperature and humidity in the greenhouse $\left(20:^{00}-06: 00\right)$ during the period of NovemberMarch are given in Figure 1. As can be seen from the figure, while outside temperature value drops to a minimum of $-4^{\circ} \mathrm{C}$, greenhouse temperature at night was kept at average $16^{\circ} \mathrm{C}$ within the range of $15^{\circ} \mathrm{C}-17^{\circ} \mathrm{C}$.

Heating in the greenhouse was started on 01.11.2014 and ended on 30.03.2015. Amounts of coal consumed during the production period are given in Table 3. As can be seen from the table, the total coal consumption of the greenhouse installed on a $20,160 \mathrm{~m}^{2}$ area was $321,500 \mathrm{~kg}$ when temperature was kept at approximately at $16^{\circ} \mathrm{C}$.This is equivalent to $15.95 \mathrm{~kg} \cdot \mathrm{m}^{-2}$ imported coal per unit greenhouse area. The highest coal consumption was in January $(100,775 \mathrm{~kg})$. The amount of coal consumed in January was $31.3 \%$ of the annual coal consumption.

Heat consumption calculated with the method considering temperature rise in the greenhouse (Method 1), daily heat consumption calculated theoretically considering temperature difference (Method 2) and heat consumption with coal consumed under real conditions are given in Figure 2. As can be seen in the figure, heat consumption calculated theoretically with two different methods shows differences when compared to actual heat energy consumed. This is mainly due to the fact that climatic data used in theoretical calculations are long-year average hourly values and that they show differences from climatic values of 2014-2015 when actual heat consumption measurements were made. The deviations between the values are proportionately higher during warmer transition periods while they are lower in colder periods.

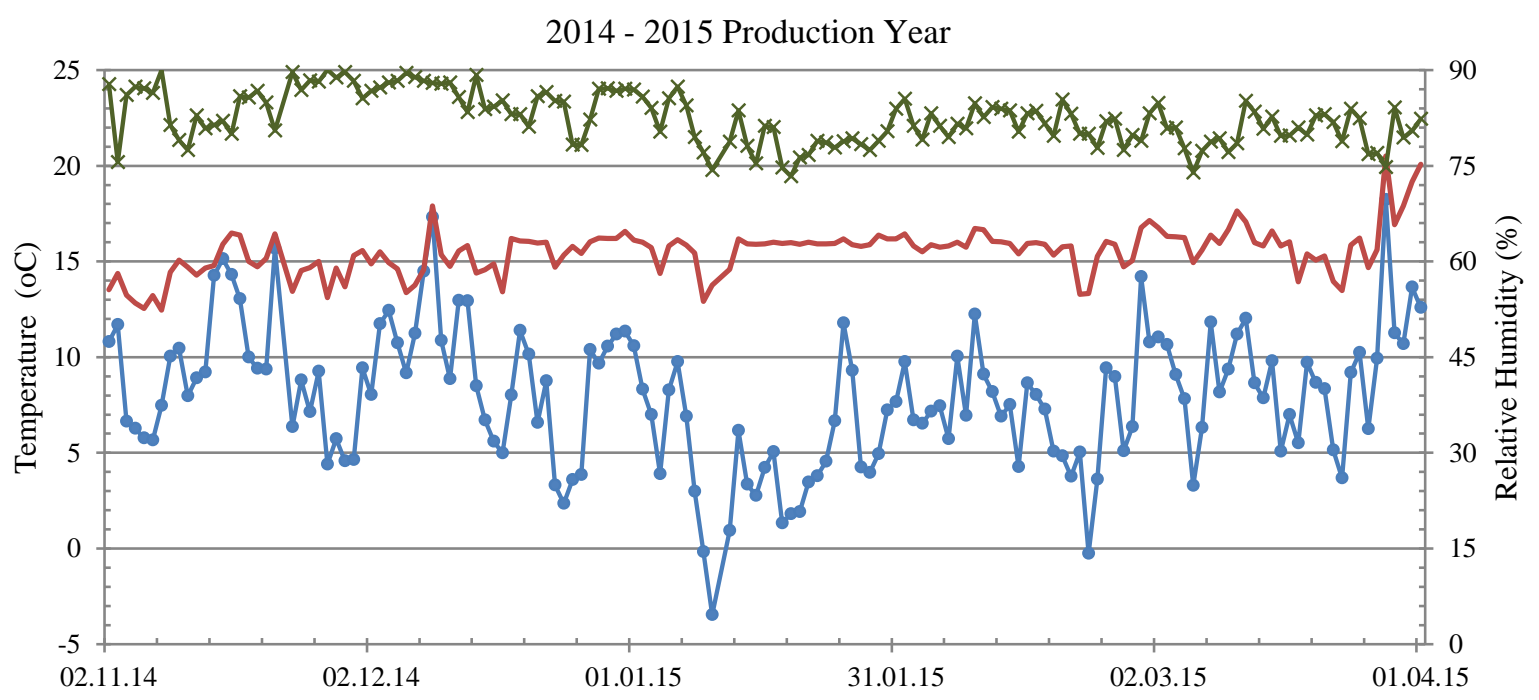

$\longrightarrow$ Outside Temperature $\quad$ Greenhouse Temperature $\quad \leftarrow$ RH \%

Figure 1 Average night temperature and humidity values measured in the PE plastic greenhouse during the perid of November-March $\left(20:^{00}-06:^{00}\right)$ 
Table 3 Amount of coal consumed in a PE plastic greenhouse installed on a $20,160 \mathrm{~m}^{2}$ area when temperature was kept at $16^{\circ} \mathrm{C}$

\begin{tabular}{l|ccccc}
\hline \multirow{2}{*}{ Day } & \multicolumn{3}{c}{2014} & \multicolumn{2}{c}{2015} \\
\cline { 2 - 6 } & November & December & January & February & March \\
\cline { 2 - 6 } & \multicolumn{4}{c}{ Coal Consumption } \\
\hline Monthly total consumption (kg.month $\left.{ }^{-1}\right)$ & 43,700 & 71,675 & 100,775 & 67,600 & 37,750 \\
Monthly consumption percentage $(\%)$ & 13.6 & 22.3 & 31.3 & 21.0 & 11.7 \\
Accumulated consumption $(\mathrm{kg})$ & 43,700 & 115,375 & 216,150 & 283,750 & 321,500 \\
Accumulated consumption $\left(\mathrm{kg} . \mathrm{m}^{-2}\right)$ & 2.17 & 5.73 & 10.72 & 14.07 & 15.95 \\
\hline
\end{tabular}

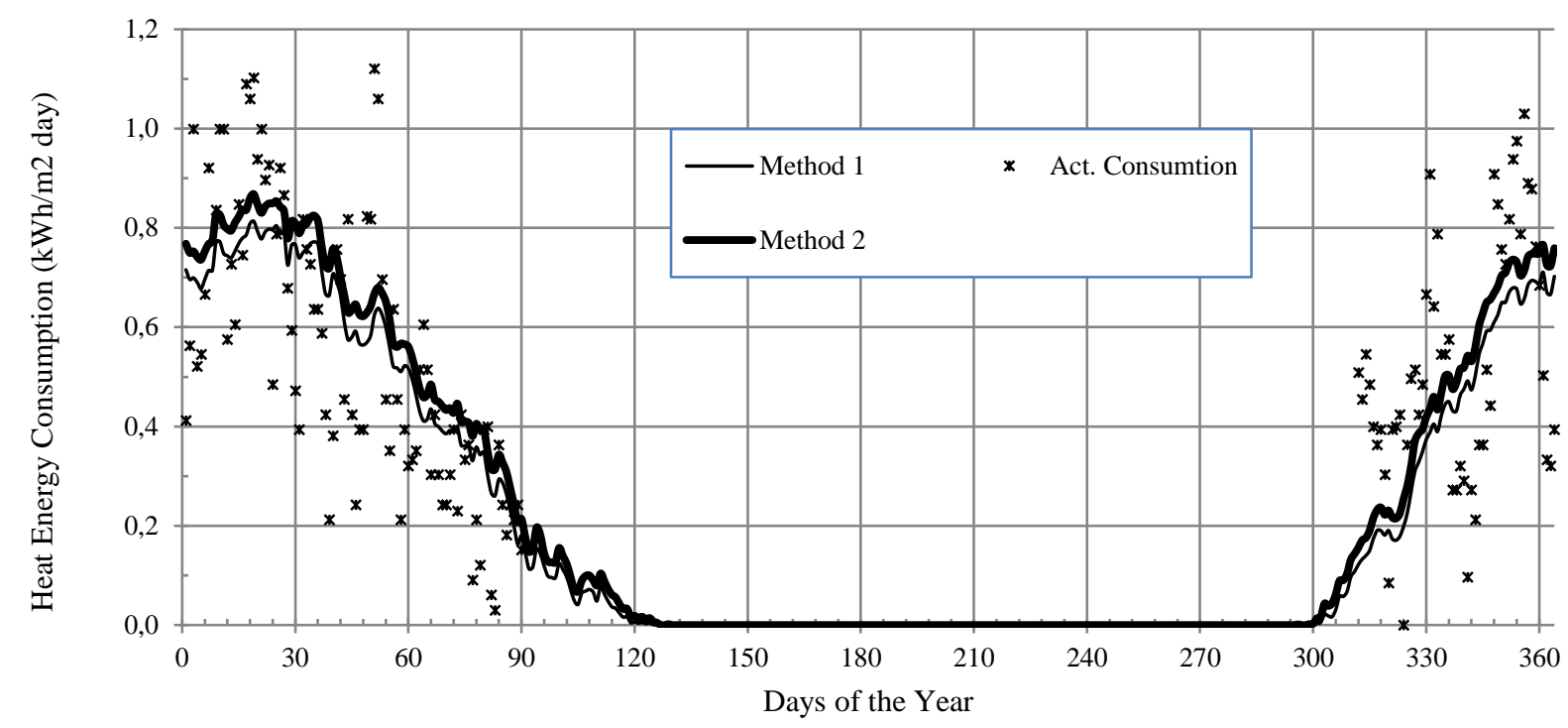

Figure 2 Daily heat energy calculated theoretically with different methods when temperature was kept at $16^{\circ} \mathrm{C}$ in the $\mathrm{PE}$ plastic greenhouse with a thermal curtain

Actual coal consumption in the PE plastic greenhouse and heat consumption calculated theoretically with two different methods per unit greenhouse area are given in Table 4. As can be seen in the table, heat energy consumption per unit greenhouse was the highest in January according to both calculation methods and actual consumption. Heat consumption calculated per unit greenhouse in January according to the method considering temperature rise (Method 1) was $23.43 \mathrm{kWh}$ $\mathrm{m}^{-2}$ month ${ }^{-1}$ while heat consumption calculated according to temperature difference was $25.07 \mathrm{kWh} \mathrm{m}^{-2} \mathrm{month}^{-1}$. In January, heat consumption calculated according to the actual coal consumption in the greenhouse was 24.43 $\mathrm{kWh} \mathrm{m}^{-2}$ month $^{-1}$.

Differences between theoretical calculations made with two different methods and actual values of heat consumption were observed. The difference between heat consumption calculated theoretically and actual heat consumption decreased in colder periods and increased during the months of the transition periods.

Monthly coal consumption of the greenhouse during the production period and coal consumption calculated with the two methods are given in Table 5. As can be seen from the chart, actual amount of coal consumed in the greenhouse during the production period was $15.95 \mathrm{~kg} . \mathrm{m}^{-}$ ${ }^{2} \mathrm{a}^{-1}$ while coal consumption calculated theoretically according to the method considering temperature rise was $15.45 \mathrm{~kg} . \mathrm{m}^{-2} \mathrm{a}^{-1}$ andcoal consumption calculated according to temperature difference was $16.93 \mathrm{~kg} \cdot \mathrm{m}^{-2} \mathrm{a}^{-1}$.
As a result of calculations made for January, the closest figure to actual heat consumption was obtained with the calculations based on the inside and outside temperature difference (Method 2). Heat consumption during the production period calculated with two different methods and heat consumption calculated according to actual coal consumption are given in Figure 3. As can be seen in the figure, according to the method considering heat rise (Method 1) heat consumption calculated was $3.0 \%$ lower than actual heat consumption while according to the method considerind temperature difference (Method 2) the resulting value was $6.3 \%$ higher than actual consumption.

A graphical representation of weekly coal consumption amounts calculated theoretically with two different methods and actual coal consumption of a PE plastic greenhouse with a thermal curtain for Adana climatic conditions are given in Figure 4. As can be seen from the figure, no significant difference was observed between the theoretically calculated coal consumption and actual consumption. While coal consumption calculated theoretically considering temperature rise in the greenhouse (Method 1) was $15.45 \quad \mathrm{~kg} \cdot \mathrm{m}^{-2} \mathrm{a}^{-1}$ and consumption calculated considering inside and outside temperature difference (Method 2) was $16.93 \mathrm{~kg} \cdot \mathrm{m}^{-2} \mathrm{a}^{-1}$, the amount of coal actually consumed in the greenhouse was $15.95 \mathrm{~kg} \cdot \mathrm{m}^{-2} \mathrm{a}^{-1}$.According to the results obtained, fuel consumption determined considering temperatre rise provided a closer value to the actual amount of fuel consumed. 
Table 4 Daily heat energy consumption calculated theoretically with two different methods and actual heat energy consumption in the plastic greenhouse (kWh.m ${ }^{-2}$ day $\left.^{-1}\right)$

\begin{tabular}{|c|c|c|c|c|c|c|c|c|c|c|c|c|c|c|c|}
\hline \multirow{2}{*}{$\mathrm{D}$} & \multicolumn{3}{|c|}{ January } & \multicolumn{3}{|c|}{ February } & \multicolumn{3}{|c|}{ March } & \multicolumn{3}{|c|}{ November } & \multicolumn{3}{|c|}{ December } \\
\hline & M1 & M2 & $\mathrm{AC}$ & M1 & M2 & $\mathrm{AC}$ & M1 & M2 & $\mathrm{AC}$ & M1 & M2 & $\mathrm{AC}$ & M1 & M2 & $\mathrm{AC}$ \\
\hline 1 & 0.72 & 0.77 & 0.41 & 0.75 & 0.80 & 0.82 & 0.52 & 0.56 & 0.32 & & & & 0.44 & 0.50 & 0.55 \\
\hline 2 & 0.70 & 0.75 & 0.56 & 0.76 & 0.81 & 0.76 & 0.50 & 0.54 & 0.33 & & & & 0.45 & 0.50 & 0.58 \\
\hline 3 & 0.70 & 0.75 & 1.00 & 0.77 & 0.82 & 0.73 & 0.46 & 0.51 & 0.35 & & & & 0.43 & 0.48 & 0.27 \\
\hline 4 & 0.69 & 0.74 & 0.52 & 0.77 & 0.82 & 0.64 & 0.43 & 0.48 & 0.51 & & & & 0.43 & 0.49 & 0.27 \\
\hline 5 & 0.68 & 0.74 & 0.55 & 0.77 & 0.81 & 0.64 & 0.41 & 0.46 & 0.61 & & & & 0.46 & 0.52 & 0.32 \\
\hline 6 & 0.70 & 0.75 & 0.67 & 0.71 & 0.76 & 0.59 & 0.41 & 0.46 & 0.51 & & & & 0.48 & 0.52 & 0.29 \\
\hline 7 & 0.71 & 0.77 & 0.92 & 0.67 & 0.72 & 0.42 & 0.44 & 0.48 & 0.30 & & & & 0.49 & 0.54 & 0.10 \\
\hline 8 & 0.71 & 0.77 & 1.24 & 0.66 & 0.72 & 0.21 & 0.41 & 0.45 & 0.42 & 0.12 & 0.16 & 0.51 & 0.47 & 0.53 & 0.27 \\
\hline 9 & 0.77 & 0.83 & 0.84 & 0.71 & 0.76 & 0.38 & 0.40 & 0.45 & 0.30 & 0.13 & 0.17 & 0.45 & 0.50 & 0.56 & 0.21 \\
\hline 10 & 0.77 & 0.83 & 1.00 & 0.69 & 0.74 & 0.76 & 0.39 & 0.44 & 0.24 & 0.14 & 0.18 & 0.55 & 0.54 & 0.60 & 0.36 \\
\hline 11 & 0.75 & 0.81 & 1.00 & 0.66 & 0.70 & 0.70 & 0.39 & 0.43 & 0.24 & 0.15 & 0.19 & 0.48 & 0.57 & 0.63 & 0.36 \\
\hline 12 & 0.74 & 0.80 & 0.58 & 0.61 & 0.66 & 0.45 & 0.39 & 0.44 & 0.30 & 0.17 & 0.22 & 0.40 & 0.59 & 0.65 & 0.51 \\
\hline 13 & 0.74 & 0.79 & 0.73 & 0.57 & 0.63 & 0.82 & 0.39 & 0.43 & 0.39 & 0.19 & 0.23 & 0.36 & 0.59 & 0.66 & 0.44 \\
\hline 14 & 0.75 & 0.81 & 0.61 & 0.58 & 0.64 & 0.42 & 0.40 & 0.45 & 0.23 & 0.19 & 0.24 & 0.39 & 0.61 & 0.67 & 0.91 \\
\hline 15 & 0.77 & 0.82 & 0.85 & 0.59 & 0.65 & 0.24 & 0.36 & 0.41 & 0.42 & 0.18 & 0.22 & 0.30 & 0.62 & 0.68 & 0.85 \\
\hline 16 & 0.78 & 0.84 & 0.74 & 0.57 & 0.63 & 0.39 & 0.36 & 0.41 & 0.33 & 0.19 & 0.23 & 0.08 & 0.65 & 0.70 & 0.76 \\
\hline 17 & 0.79 & 0.84 & 1.09 & 0.56 & 0.62 & 0.39 & 0.36 & 0.41 & 0.36 & 0.17 & 0.22 & 0.39 & 0.65 & 0.71 & 0.73 \\
\hline 18 & 0.81 & 0.86 & 1.06 & 0.57 & 0.63 & 0.82 & 0.33 & 0.38 & 0.09 & 0.17 & 0.21 & 0.40 & 0.67 & 0.73 & 0.82 \\
\hline 19 & 0.81 & 0.87 & 1.10 & 0.58 & 0.64 & 0.82 & 0.36 & 0.41 & 0.21 & 0.18 & 0.22 & 0.42 & 0.68 & 0.74 & 0.94 \\
\hline 20 & 0.79 & 0.85 & 0.94 & 0.63 & 0.67 & 1.12 & 0.34 & 0.39 & 0.12 & 0.20 & 0.25 & 0.00 & 0.68 & 0.73 & 0.98 \\
\hline 21 & 0.78 & 0.83 & 1.00 & 0.64 & 0.68 & 1.06 & 0.35 & 0.40 & 0.39 & 0.23 & 0.28 & 0.36 & 0.65 & 0.70 & 0.79 \\
\hline 22 & 0.79 & 0.84 & 0.90 & 0.63 & 0.67 & 0.70 & 0.30 & 0.35 & 0.40 & 0.27 & 0.32 & 0.50 & 0.66 & 0.71 & 1.03 \\
\hline 23 & 0.80 & 0.85 & 0.93 & 0.60 & 0.65 & 0.45 & 0.27 & 0.31 & 0.06 & 0.31 & 0.37 & 0.51 & 0.68 & 0.74 & 0.89 \\
\hline 24 & 0.80 & 0.85 & 0.48 & 0.56 & 0.62 & 0.35 & 0.26 & 0.31 & 0.03 & 0.33 & 0.39 & 0.42 & 0.69 & 0.75 & 0.88 \\
\hline 25 & 0.80 & 0.85 & 0.79 & 0.52 & 0.57 & 0.64 & 0.29 & 0.34 & 0.36 & 0.35 & 0.39 & 0.48 & 0.69 & 0.75 & 0.76 \\
\hline 26 & 0.79 & 0.84 & 0.92 & 0.52 & 0.56 & 0.45 & 0.29 & 0.33 & 0.24 & 0.37 & 0.42 & 0.67 & 0.69 & 0.75 & 0.68 \\
\hline 27 & 0.79 & 0.83 & 0.87 & 0.51 & 0.57 & 0.21 & 0.26 & 0.31 & 0.18 & 0.39 & 0.44 & 0.91 & 0.71 & 0.77 & 0.5 \\
\hline 28 & 0.73 & 0.78 & 0.68 & 0.52 & 0.57 & 0.39 & 0.23 & 0.28 & 0.24 & 0.40 & 0.46 & 0.64 & 0.67 & 0.73 & 0.33 \\
\hline 29 & 0.77 & 0.81 & 0.59 & & & & 0.20 & 0.24 & 0.21 & 0.39 & 0.43 & 0.79 & 0.67 & 0.72 & 0.32 \\
\hline 30 & 0.77 & 0.81 & 0.47 & & & & 0.16 & 0.21 & 0.24 & 0.42 & 0.47 & 0.55 & 0.70 & 0.76 & 0.39 \\
\hline 31 & 0.74 & 0.79 & 0.39 & & & & 0.18 & 0.21 & 0.15 & & & & & & 0.27 \\
\hline $\mathrm{T}$ & 23.43 & 25.07 & 24.43 & 17.69 & 19.12 & 16.37 & 10.84 & 12.28 & 9.08 & 5.65 & 6.71 & 10.56 & 17.83 & 19.51 & 17.36 \\
\hline
\end{tabular}

D: Day, T: Total, M1: Method 1, M2: Method 2, AC: Actual Consumption

Table 5 Coal consumption of a greenhouse with a thermal curtain calculated with different methods for Adana climatic conditions when temperature is kept at $16^{\circ} \mathrm{C}$.

\begin{tabular}{l|cccccc}
\hline \multirow{2}{*}{\multicolumn{1}{c|}{ Method }} & \multicolumn{5}{c}{ Coal consumption $\left(\mathrm{kg} \cdot \mathrm{m}^{-2} \mathrm{month}^{-1}\right)$} \\
\cline { 2 - 6 } & November & December & January & February & March & Total \\
\hline Actual consumption & 2.17 & 3.56 & 5.00 & 3.35 & 1.87 & 15.95 \\
Calculated with Method 1 & 1.16 & 3.65 & 4.80 & 3.62 & 2.22 & 15.45 \\
Calculated with Method 2 & 1.37 & 3.99 & 5.13 & 3.91 & 2.51 & 16.93 \\
\hline
\end{tabular}

Weekly actual fuel consumption and fuel consumption calculated theoretically with two different methods were evaluated statistically and the relations obtained are given below. In the statistical evaluation made with the three methods, fuel consumption and high correlation were obtained (M1: Method 1, M2: Method 2, AC: Actual Consumption)

AC $y=-0.003 x^{3}+0.091 x^{2}+0.165 x+0.188 R^{2}=0.999$

M1 $y=-0.003 x^{3}+0.102 x^{2}-0.011 x+0.033 R^{2}=0.999$

M2 $y=-0.003 x^{3}+0.103 x^{2}+0.060 x+0.004 R^{2}=0.999$

Heat consumption in greenhouses should be calculated based on hourly values. In calculations made using hourly values, heat consumption coefficient $\left(U_{c S}\right)$ should definitely be determined according to wind speed. Total heat consumption coefficients given in technical literature are for $4 \mathrm{~m} . \mathrm{s}^{-1}$ wind speed. When calculating heat requirements in greenhouses, instead of the outside temperature, the actual temperature in unventilated and unheated greenhouses and the temperature rise due to greenhouse specifications should be taken into consideration. The heat energy stored in the greenhouse during the day, which depends on the greenhouse specifications and equipment, has influence on reducing heat consumpton in the greenhouse. For this reason, heat consumption calculations made by taking into consideration heat rises in the greenhouse and actual temperature values provide results that are closer to actual consumption values. 


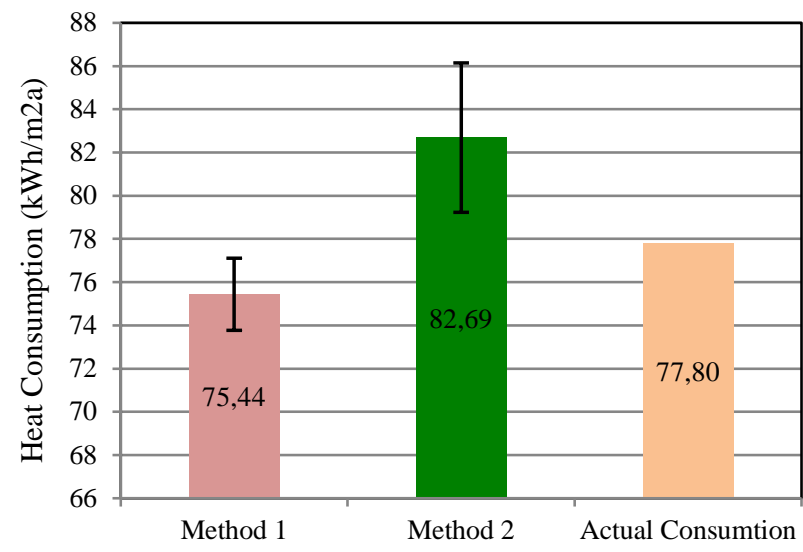

Figure 3 Heat consumption of a PE plastic greenhouse with a thermal curtain calculated with two different methods and heat consumption calculated according to actual coal consumption for Adana climatic conditions when temperature is kept at $16^{\circ} \mathrm{C}\left(\mathrm{kWh} \cdot \mathrm{m}^{-2} \mathrm{a}^{-1}\right)$

In the study, a very small difference like $3.0 \%$ was found between coal consumed during the production period in a high technology PE plastic greenhouse in Adana climatic conditions and consumption amounts obtained with theoratical calculations considering temperature rises. This outcome regarding temperature rise in calculating heat requirements of greenhouses can be readily used in heat requirement calculations for greenhouses to be installed in different regions as well as in economical analyses and feasibility calculations for greenhouses.

\section{References}

Baytorun AN,Abak K, Tokgöz H, Güler Y, Üstün S. 1995. Seraların kışın iklimlendirilmesi ve denetimi üzerinde araştırmalar. Türkiye Bilimsel ve Teknik Araştırma Kurumu. Proje no TOAG-993.

Baytorun AN. 2016. Seralar. Sera Tipleri. Donanımı ve İklimlendirilmesi. Nobel Kitabevi.

Baytorun AN, Akyüz A, Üstün S. 2016. Seralarda Isitma Sistemlerinin Modellemesi ve Karar Verme Aşamasında Bilimsel Verilere Dayalı Uzman Sistemin "ISIGER-SERA" Geliştirilmesi. TÜBİTAK 1140533 nolu proje.

Çanakçı M, Emekli NY, Bilgin S, Çağlayan N. 2013. Heating requirement and cost in greenhouses. A case study for Mediterranean region of Turkey. Renewable and Sustainable Energy Reviews 24.sy.483-490.

Damrath J, Klein F L. 1983. Tabellenzur Heizenergieermittlung von Gewächshäusern. Gartenbautechnische Information ITG Hannover. Heft 18 Klima Trier.

Damrath J. 1980. Tabellenzur Heizenergieermittlung von Gewächshäusern. Gartenbautechnische Information ITG Hannover. Heft 8 Klima Hannover.

DIN 4701. 1983. Regeln für die Berechnung des Wärmebedarfs von Gebäuden. Teil 1 und Teil 2.

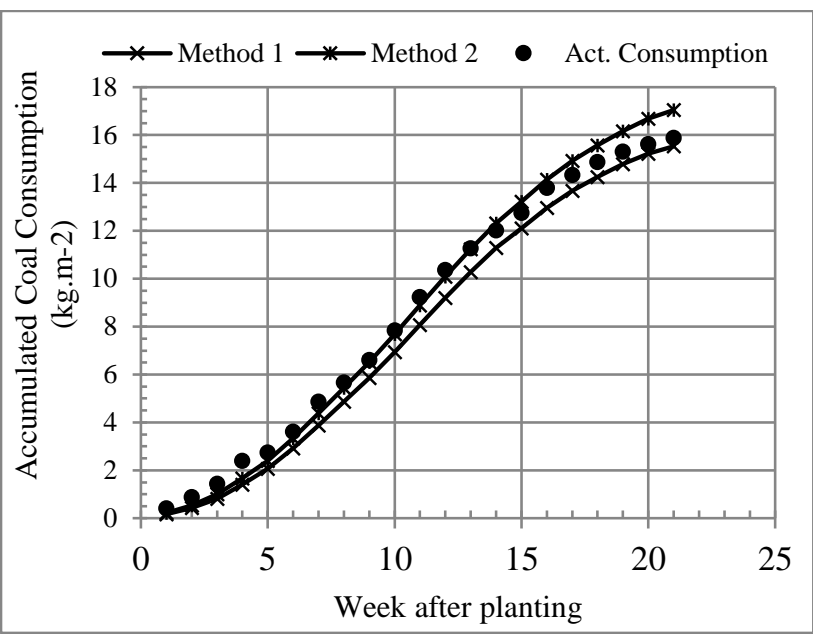

Figure 4 Accumulated coal amounts consumed in a PE plastic greenhouse during the production period and consumption amounts calculated with different methods for Adana climatic conditions $\left(\mathrm{kg} \cdot \mathrm{m}^{-2}\right)$

Meyer J. 2008. Nomenklatur und Definitionen Bericht zur Bestimmung und Bewertung des Energiebedarfs von Gewächshäusern. KTBL Workshop. 17 September 2008. S.14-22.

Müller G. 1987. Energieschierme unter Praxisbedingungen Bewertung und Optimierung im Hinblick auf Energieverbrauch und Klimaführung. Dissertation. Institut für Technik in Gartenbau und Landwirtschaft Universität Hannover.

Öztürk HH. 2011. Antalya İklimi Koşullarında Sera Isıtma Amaciyla Güneş Enerjisinin Duyulur Isı Olarak Depolanması İçin Tasarım Değişkenlerinin Belirlenmesi. İKLIMM 2011 Ulusal İklimlendirme Kongresi. ANTALYA. TÜRKIYE. 4-5 Aralık. s. 209-224

Rath T. 1992. Einsatz wissenbasierter Systeme zur Modellirung und Darstellung von Gartenbautechnischen Fachwissen am Beispiel des hybrieden Expertensystems HORTEX. Gartenbautechnische Informationen. Heft 34. Institut für Technik im Gartenbau der Universitat Hannover.

Rath T. 1994. Einfluss der Wärmespeicherung auf die Berechnung des Heizenergiebedarfs von Gewächshäusern mit Hilfe des k'-Modells. Gartenbauwissenschaft 59 (1).s. 39-44.

Tantau HJ. 1983. Heizungsanlagen im Gartenbau. Verlag Eugen Ulmer. Stuttgart.

Tantau HJ.2008. Wärmeverbrauchsmessung - Einflussfaktoren. Bericht zur Bestimmung und Bewertung des Energiebedarfs von Gewächshäusern. KTBL Workshop. 17 September 2008. s. 23-30.

Tantau HJ. 2012. Das Niedrigenergiegewächshaus - Methode zur Analyse der Wärmeströme und der PARDurchlässigkeit. Landtechnik 67 (3), S. 196 - 204

Zabeltitz Chr von. 1986 Gewächshäuser.VerlagEugen Ulmer.

Zabeltitz Chr von. 2011. Integrated Greenhouse Systems for Mild Climates. Springer -Verlag Berlin Heidelberg. 